\title{
KULINTANGAN: A STUDY OF PRODUCTION PROCESS
}

\author{
Adsone Matthew Mitty Gabu \\ Faculty of Humanities, Arts \& Heritage, \\ Universiti Malaysia Sabah (UMS), Malaysia \\ (Email: adsone@ums.edu.my)
}

Accepted date: $14-04-2019$

Published date: 10-07-2019

To cite this document: Gabu, A. M. M. (2019). Kulintangan: A Study of Production Process. International Journal of Heritage, Art and Multimedia, 2(5), 80-89.

DOI: $10.35631 /$ ijham.25007

\begin{abstract}
The main purpose of this study is to document the production process of the Kulintangan. Data collection was conducted through interviews and observations. The Kulintangan, an idiophone categorized musical instrument is a set of small kettle gongs positioned straight in a single row on two cords in a small wooden frame. There is no traditional system to notate the Kulintangan as music is passed down by tradition from generation to generation. Distinctions are found in different combinations of instruments, varying dance, tempos, tunings and production process. While other musical instruments in Sabah are made from natural material, the Kulintangan is made from either zinc or bronze. The process of producing Kulintangan is a highly skilled process, handed down through generation. Five tools are used to produce a set of Kulintangan. There are 6 processes in the production of the Kulintangan, from the selection of raw material to the final product. Documenting the production process provides documented information and demonstration of the Kulintangan. Thus, revive and continues intangible cultural heritage for the future.
\end{abstract}

Keywords: Kulintangan, Idiophone, Production, Documenting, Process

\section{Introduction}

Music is significant to human life and it can be validated and performed in various ways. In all societies in the world music has existed since the dawn of civilization; the role and importance of music throughout the world can be seen and heard in all cultures: music has noticeable presence in practically all important events of a human life. Music is predominant in all aspect of human life - at births, weddings, funerals, worships, graduation and etc. (Tahir, R. M., Ghazali, G. M. 2006).

Modern music in Malaysia is a fast-growing industry. Its development has been revolutionary, as talented musicians from diverse cultural backgrounds have drawn on their rich heritages to create new forms using a combination of traditional and western instruments. In Sabah, the eastern Malaysian state in northern Borneo, traditional music is an integral part of the people. With different ethnic communities, this State has a variation of traditional vocal and musical instruments. 
Music in Sabah is typically associated with rites of passages, traditional warfare, curative and rice cultivation. The musical instruments in Sabah are classified according to chordophone, aerophone, idiophone, and membranophone. Despite the rich musical heritage of Sabah, learning traditional Sabah instruments has declined, based on a study by Pugh-Kitingan (2004), which attributed the decreasing performance of traditional music occurred to the development of electronic media such as radios, television, video and VCD players. Integrating instruments and music from diverse cultures into musical instruction had become a growing interest and awareness among music enthusiast. (Beegle 2012; Dontsa 2008; Han2002; Schmid 1992; Smith 2010). This integration promotes the study of traditional instrument and the probability to integrate traditional instruments to music document and music education.

A prominent traditional instrument found in Sabah is the Kulintangan. The Kulintangan is a set of small brass kettle gongs, classed as an ideophone musical instrument. The Kulintangan is part of the musical traditions of some indigenous communities in Sabah for over 200 years due to circulation and trade through the Brunei Sultanate and the Philippines (Pugh-Kitingan 2004). The Kulintangan can be discovered among the Brunei, Iranun, Bajau, coastal Kadazan, Kimaragang, Tobilung, Tidong and Orang Sungai communities in Sabah, with the amount of small kettle gongs varying from 8 to 12 depending upon the ethnic group (Simeon, J. J. C 2015). On the west coast of Sabah, the number of gongs in a Kulintangan set can vary from seven to nine, while on the east coast it may range from five to seven or more, depending to the ethnic group.

The Kulintangan gongs are horizontally-laid in a single row on two cords in a small wooden bed-like setting. The Kulintangan is played by striking the head of the kettle gong with two wooden beaters, each kettle varying in pitch when struck. The Kulintangan performer is usually seated comfortably on the ground in front of the kettle gongs and beats the kettle with each hand holding small wooden beaters. Unlike the Kulintang, a musical instrument of the Philippines which is similar to the Kulintangan of Sabah, the Kulintangan does not have any specific names for its kettle.

\section{Objectives of the Study}

The primary purpose of the study attempts to

1. Provide information containing written references of the Kulintangan making process.

2. Provide documentation of the Kulintangan making process in digital recording.

\section{Research Method}

There are 2 methods used in this study. The first method is conducted through the interviews and observations with experienced informants who specialize in Kulintangan making. The first destination was Kampung Sumangkap - a popular gong making destination located in Kudat District. In order to experience the performances of the Kulintangan playing, two cultural destinations were selected, Monsopiad Cultural Village located at Kampung Kuai Kandazon, Penampang and Sabah Cultural Center located in Kota Kinabalu. The second method is conducted by collecting written resources from Sabah State Museum and Sabah State Library both located in Kota Kinabalu.

\section{Playing Technique}

The Kulintangan is performed by striking the head of the Kulintangan with two wooden beaters. The right hand usually plays the melody line and the left hand performed the rhythmic patterns. Depending on the set up of the performance, the Kulintangan can be performed solo or by an ensemble. The performer could achieve two sounds: an open sound created when 
allowing the kettle to ring and decay by itself or a closed sound, achieved by damping the kettle using the end of the beaters.

There is 3 custom body postures for performing the kulintangan. The player generally selects a comfortable position to play the Kulintangan. Generally, a performer would sit on the ground or seated on a chair or standing up. However, when a performer is seated on a chair or standing, a different type of wooden frame is used to allow the performer to play freely and comfortably. There is no restriction of gender in playing the Kulintangan.

\section{Research Destination}

Kampung Sumangkap, a gong making village located in Kudat District, was founded in 1973 pioneered by a man named Omlunru (informant). The village has a very distinctive attraction as a gong making centre to almost all ethnic communities in Sabah. Kudat is located at the tip of Sabah, approximately 3 hours' drive from Kota Kinabalu. The home of the Rungus people, Kudat is recognized for the rich and vivid colourful bead necklace and bracelet, as well as the Rungus longhouse. Kampung Sumangkap is a typical village with houses built closely to each other. There are workshops along the roadside, which double as a shop.

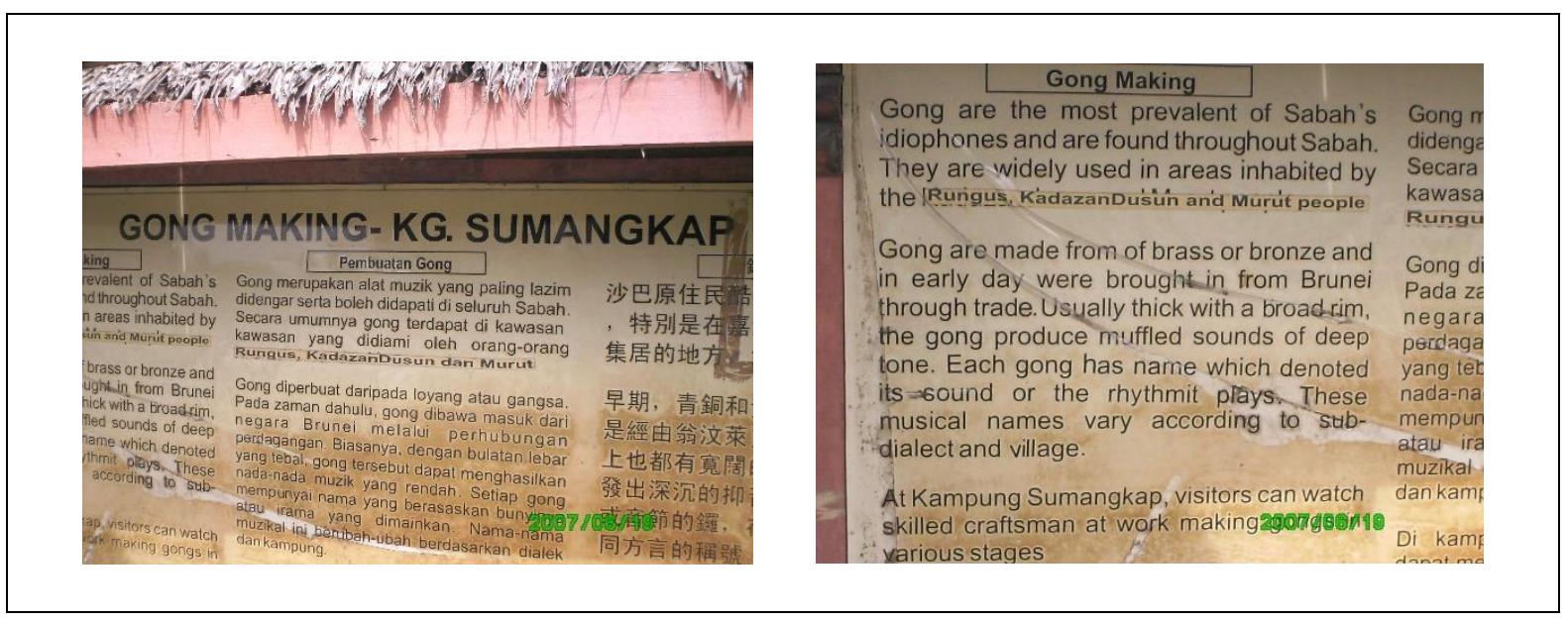

Figure 1: Kampung Sumangkap

\section{The Working Station}

Most of the working stations are built at the left and right sides of the roadside. There are several functions of the working station. The main function of the working station is to produce gongs. It also functions as an exhibition centre for the gongs and a performance venue to play the Kulintangan. Interested buyers can purchase any gong at the working station. The process of making the Kulintangan is a highly skill craft, handed down through the generations.

The Kulintangan is made from zinc or bronze. The significant difference between both materials is the sound quality and the value. The Kulintangan made from zinc is estimated to cost between RM300.00 to RM400.00, whereas the Kulintangan made from bronze is estimated to cost between RM800.00 to RM1500.00. The duration of producing the Kulintangan is different according to the material used. The Kulintangan produced using the zinc may take at least 3 days to complete, whereby using bronze may take at least a week to complete. It is recommended that a $16 \mathrm{~mm}, 20 \mathrm{~mm}$ or $30 \mathrm{~mm}$ thickness of zinc or bronze is used to produce the Kulintangan. 


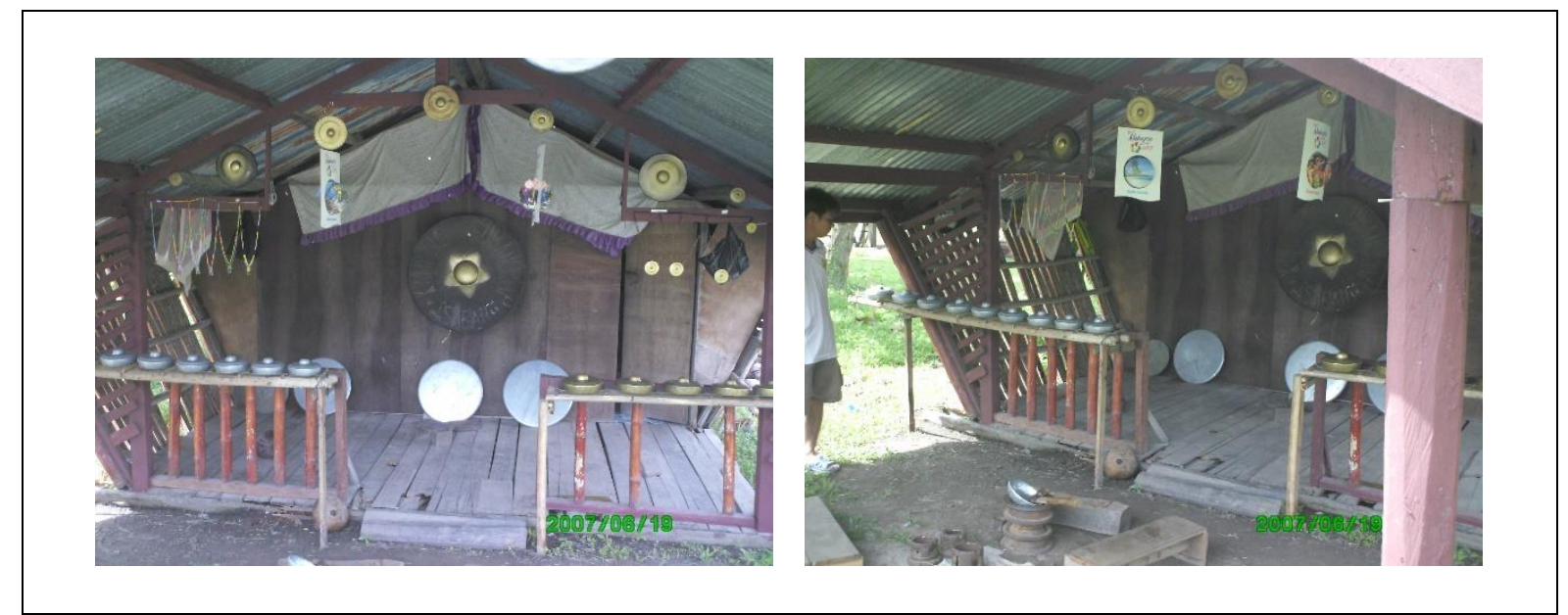

Figure 2: The Work Station

Tools used to produce the Kulintangan:

1. Raw Material: Zinc or Bronze

2. Penyukat: A self-made measurement

3. Pahat: Chisel

4. Tukul: A set of hammers

5. Dansalan: 2 sizes of dansalan

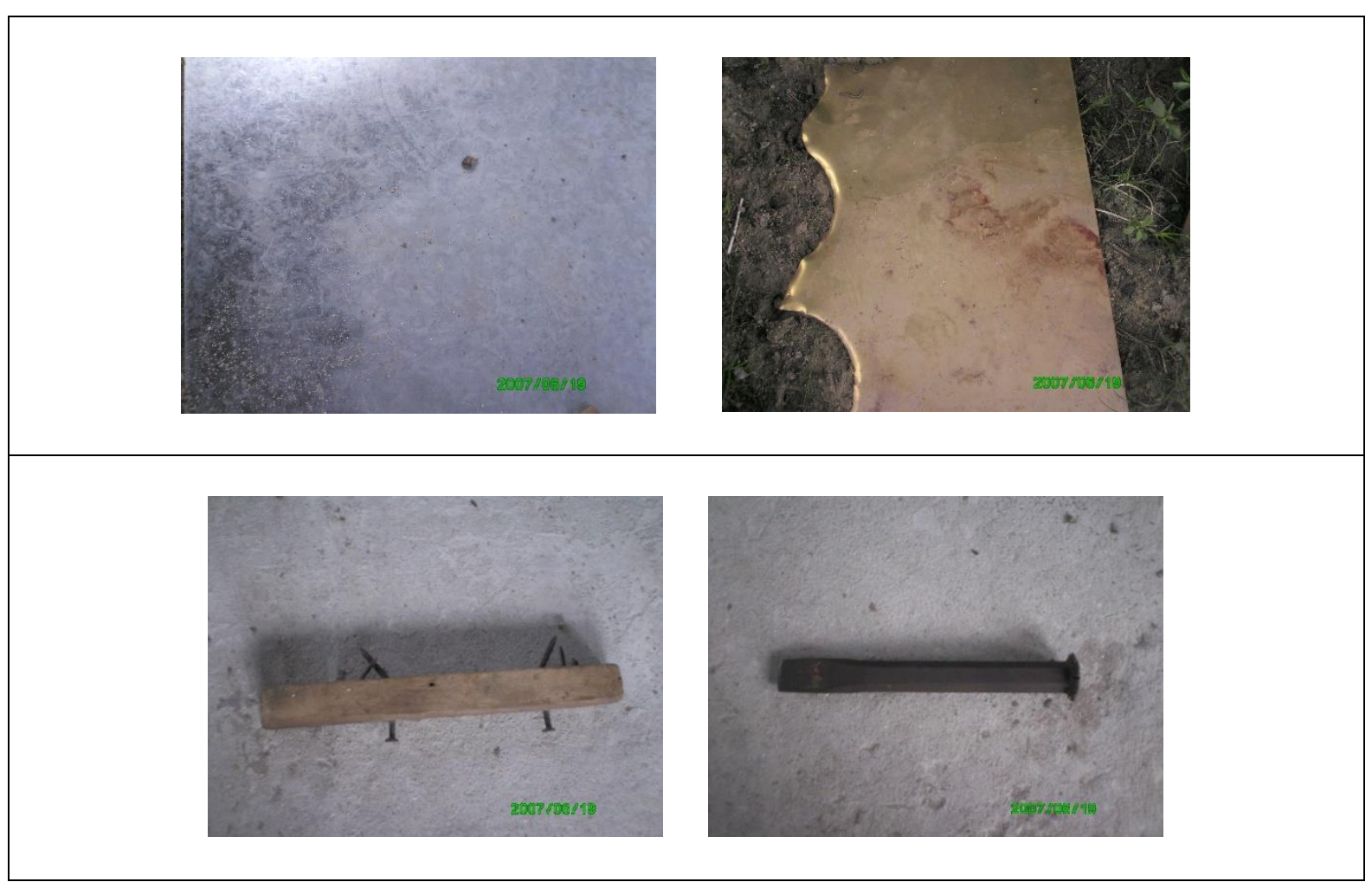

Figure 3: Instruments Used to Make the Kulintangan 


\section{The Production Process of the Kulintangan}

The first process is to choose the raw material. The maker of the Kulintangan will need to decide on which raw material to be used. This is usually determined based on orders from buyers or for personal collection (informant).

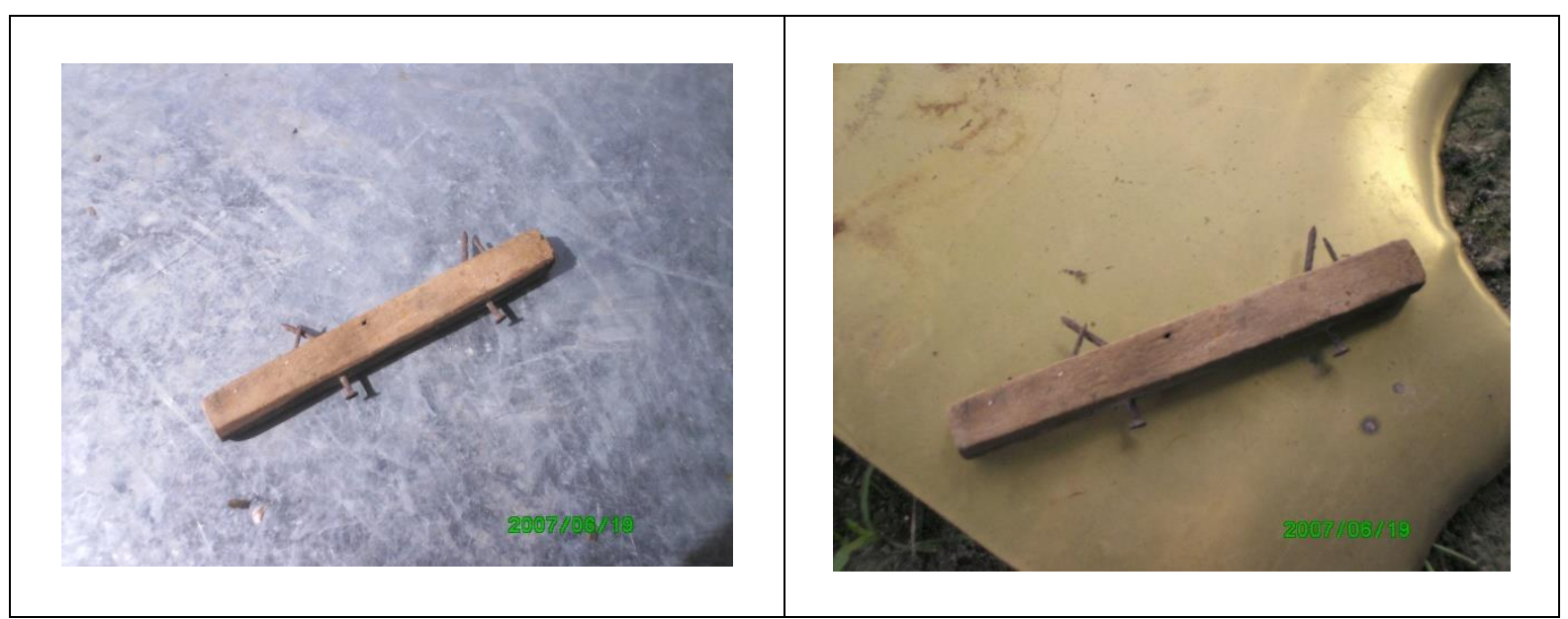

Figure 4: The $1^{\text {st }}$ Production Process

The second process is the mark the diameter of the raw material. After selecting the raw material, a maker will use a self-made measurement to mark the diameter. The penyukat measuring at about $9 \mathrm{~cm}$ is used to mark the diameter of the raw material before it is cut according to the mark made. The self-made penyukat (measurement) is made from a wood with nails as the diameter marker (Informant).

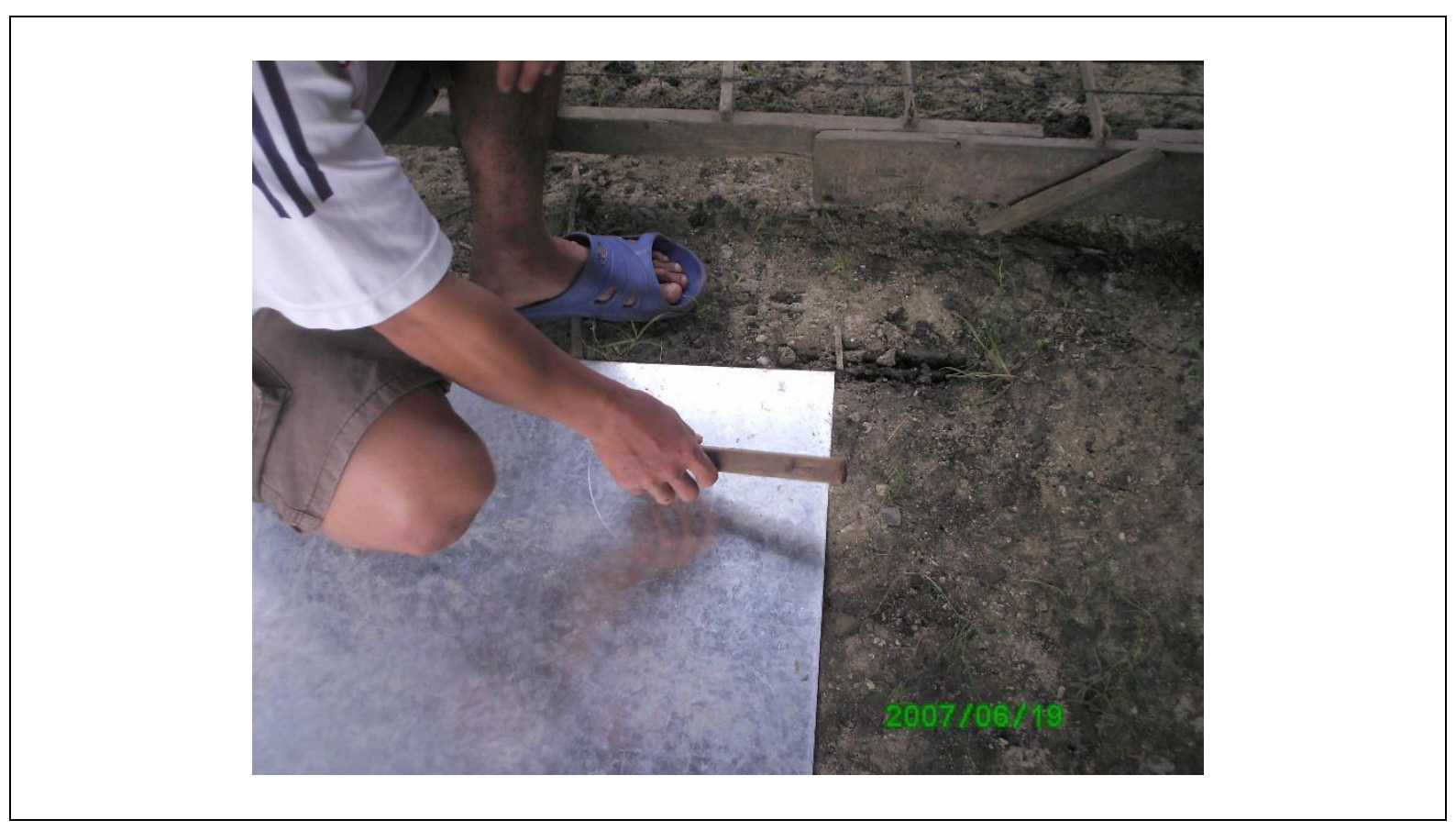

Figure 5: The $2^{\text {nd }}$ Production Process

The third process is to cut the diameter on the raw material using the pahat and the tukul From the marking made from the penyukat the maker will cut the raw material with the chisel 
carefully. Using the tukul, to knock against the pahat, completing the whole diameter. After completing the cut, the maker will then move to the next process (informant).

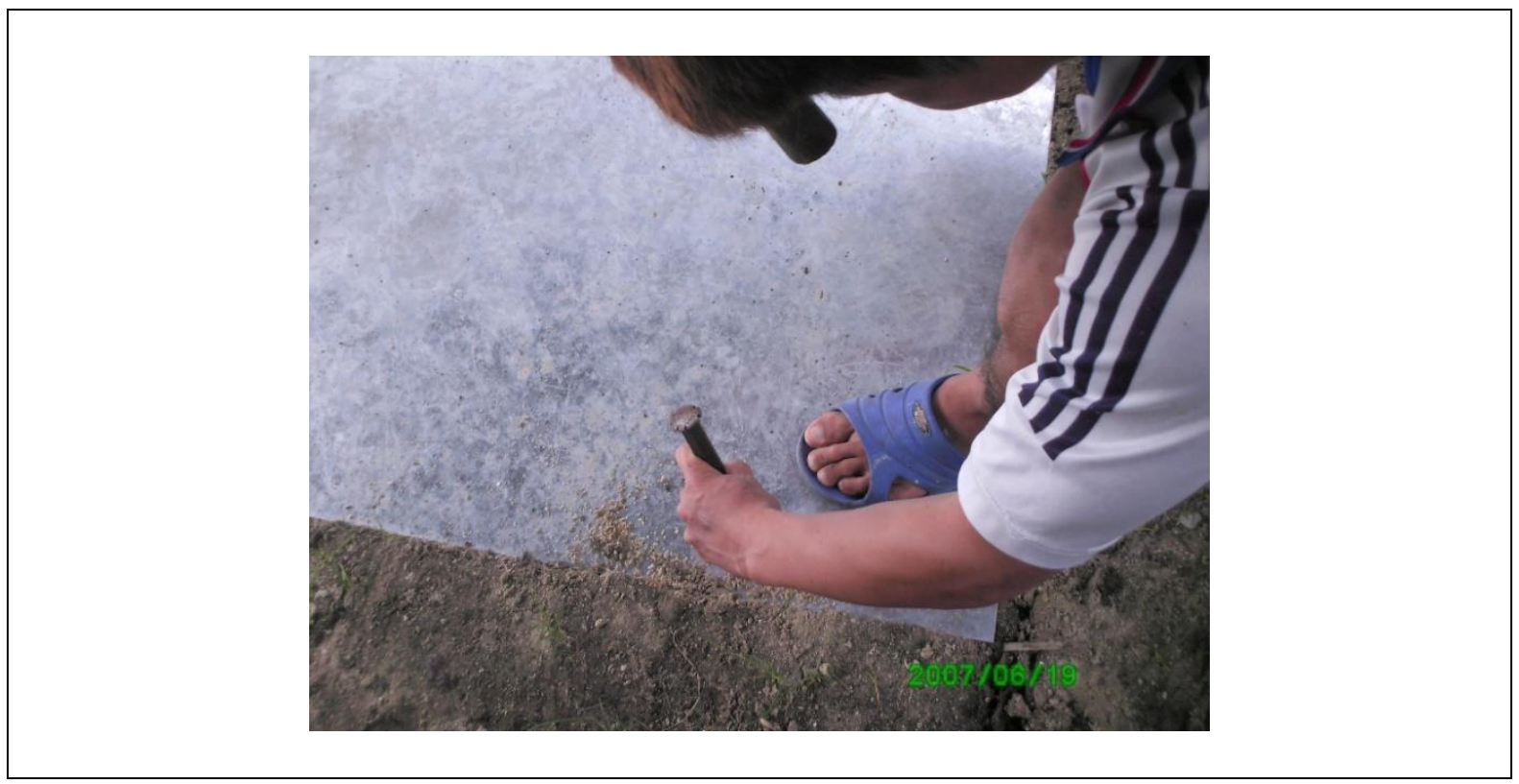

Figure 6: The $3^{\text {rd }}$ Production Process

The fourth process is to shape the cut raw material. This requires a lot of patience because the raw material needs to be knocked until the desirable shape is attained. By using the tukul, the raw material is then knocked. At this point the maker is seated on a wooden made stool. Here the maker will use a big dansalan to create a desirable shape for the raw material. A transition of 3 shapes can be observed here (informant).

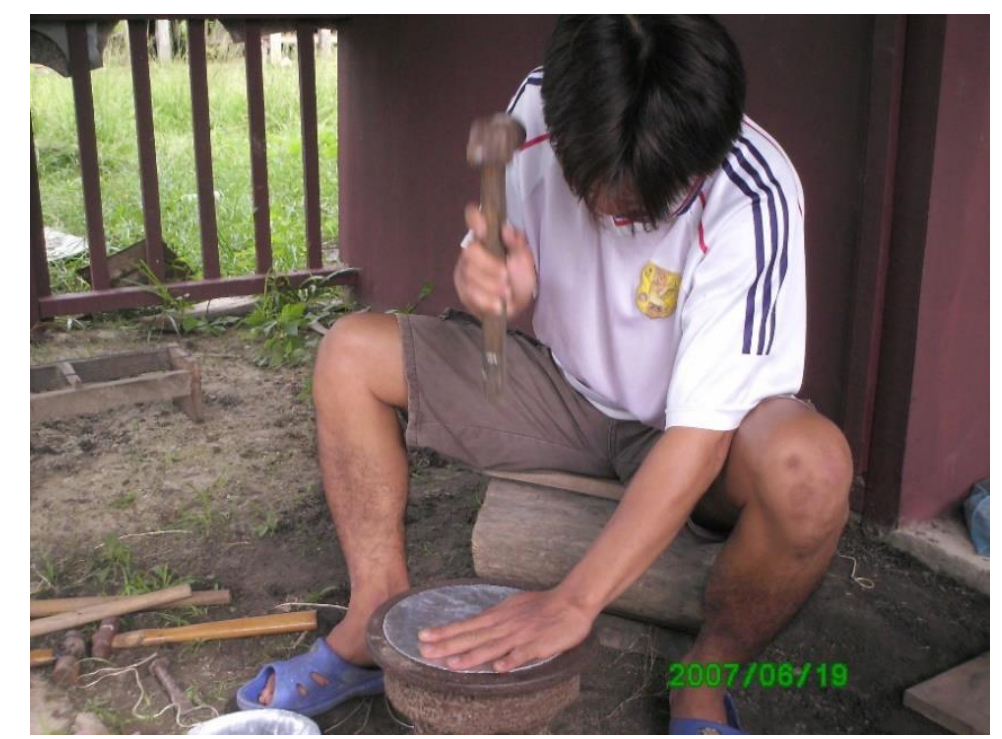

Figure 7: The $4^{\text {th }}$ Production Process 


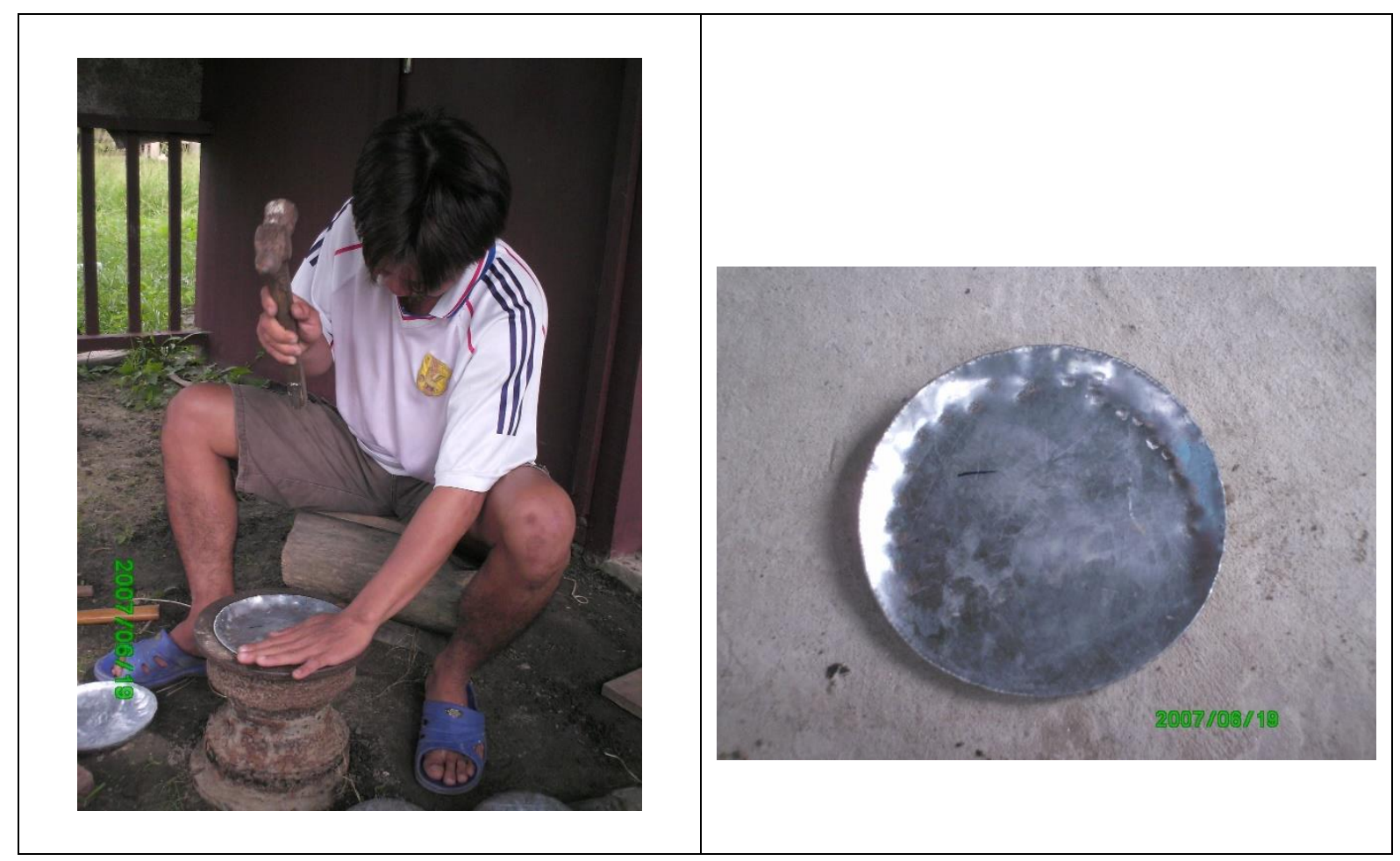

Figure 8: Shape 1

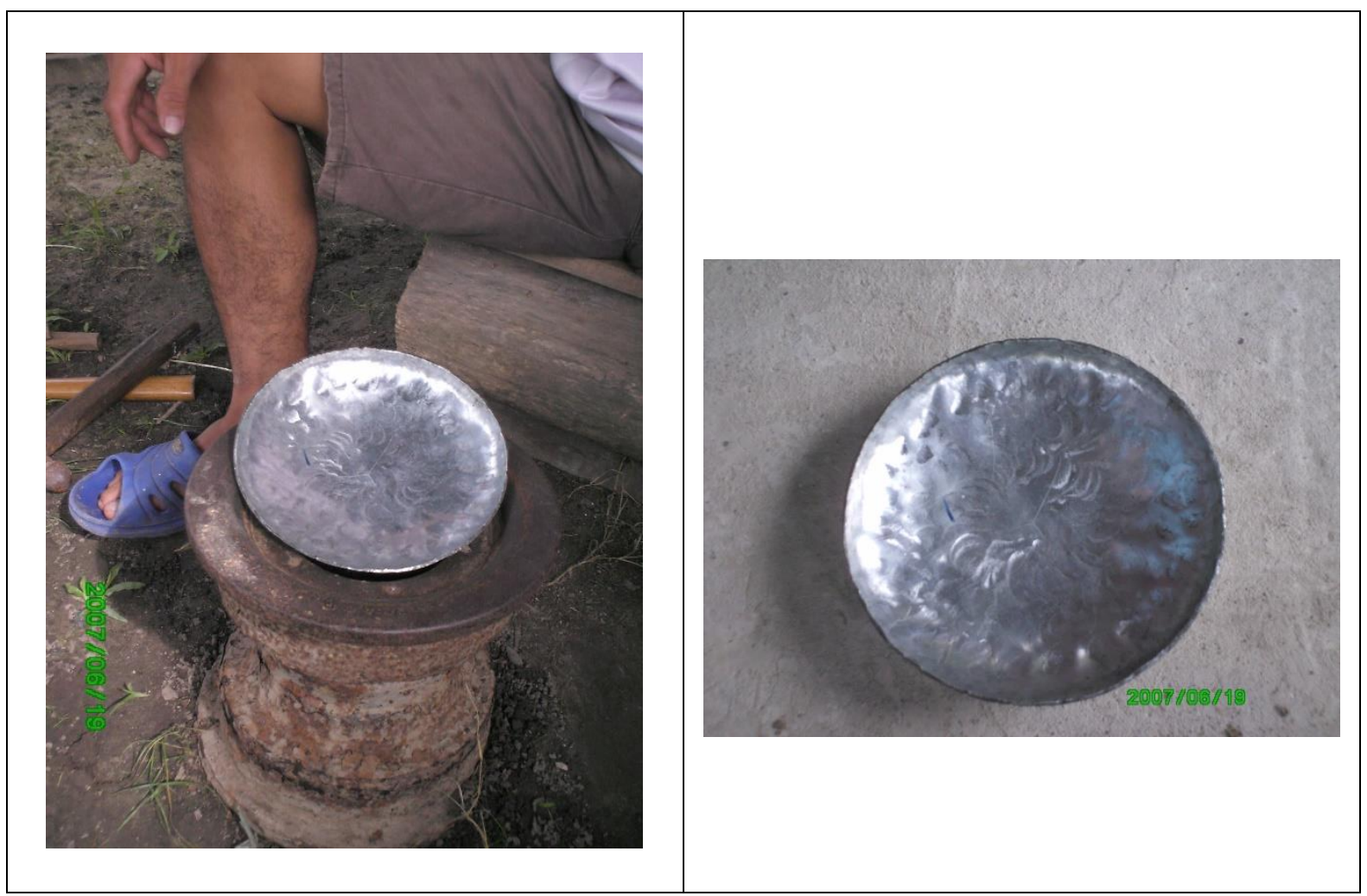

Figure 9: Shape 2 


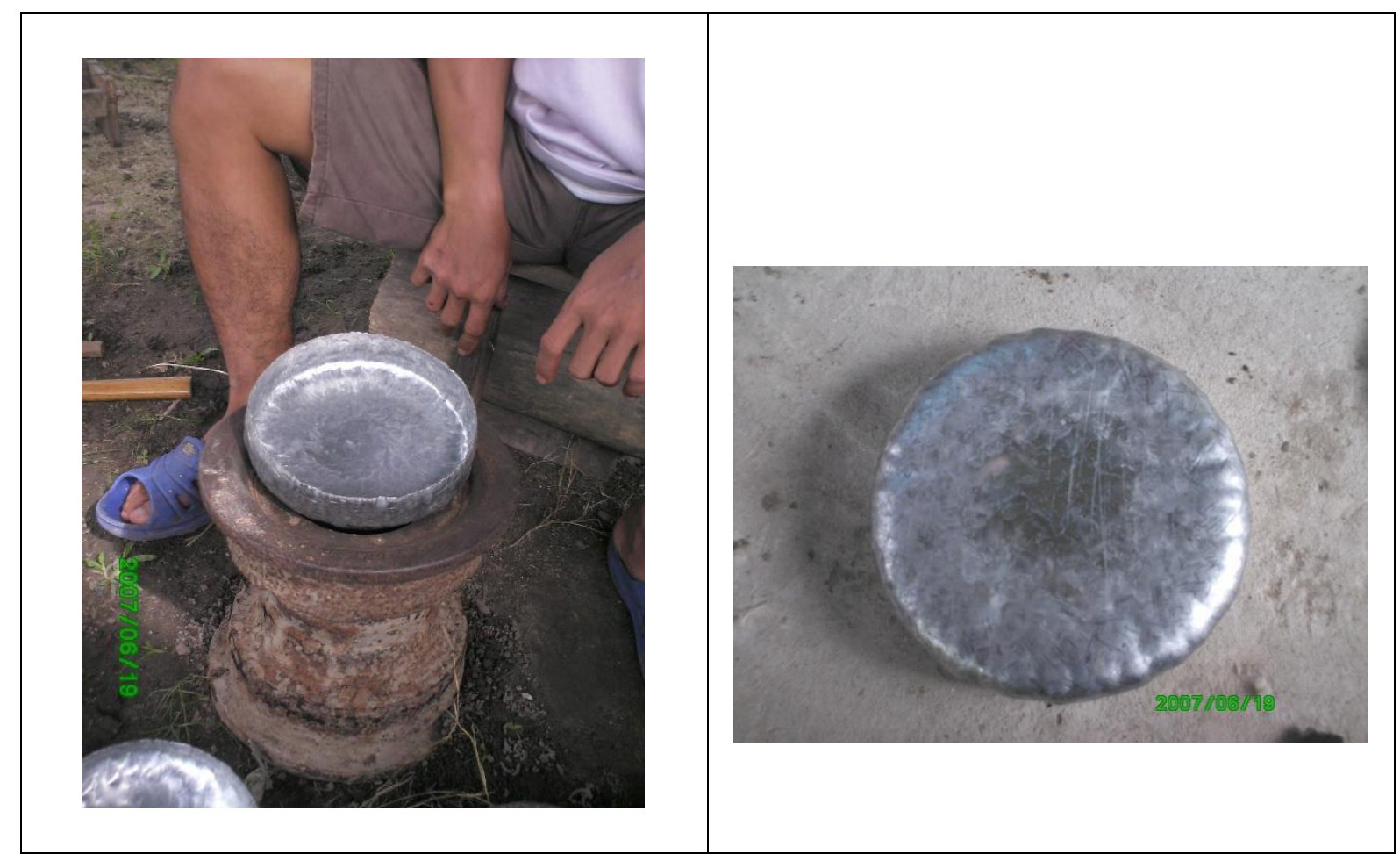

Figure 10: Shape 3

The fifth process is to create angle to the raw material. After the transition of 3 shapes using the bigger dansalan, the raw material is then transferred to a smaller size dansalan. Here the smaller dansalan is used to create angle which is the head part of the raw material. Using the hammer and chisel, careful knocking motion against the smaller dansalan is emphasised to slowly create the head of the raw material (informant).

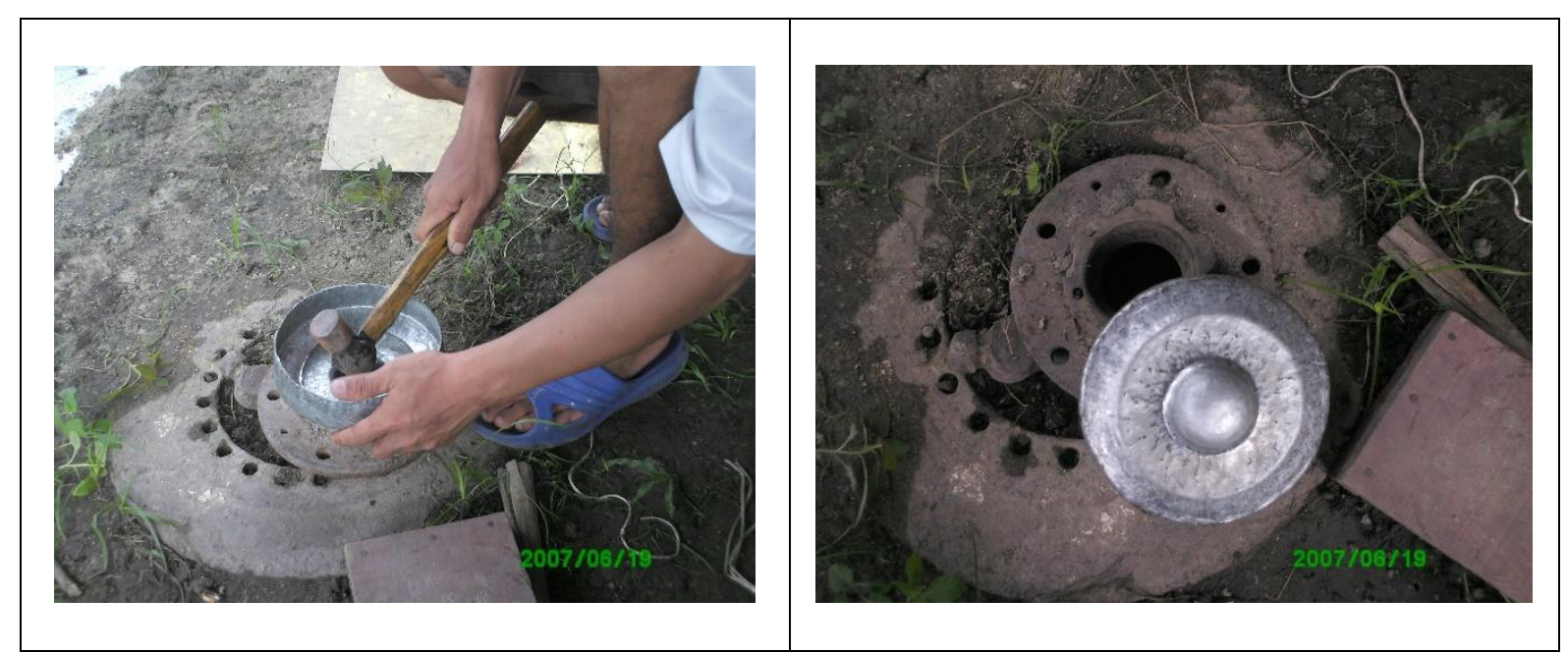

Figure 11: The $5^{\text {th }}$ Production Process

The final process of making the Kulintangan is the tuning process. In the past, the Kulintangan sets throughout Sabah are tuned by ear; there is no fixed pitch unlike western instrumentation. The Kulintangan is tuned to an anhemitonic pentatonic pitch to which makers or performer desire. Distinction between each set of Kulintangan can be realized by the raw material used 
in producing a set of Kulintangan; hence, this gives each set an exclusive pitch level, intervals and timbre (informant).

Knocking the outside part of the Kulintangan will enable a lower pitch and knocking the inner part of the Kulintangan will enable a higher pitch. This process is easier on brass Kulintangan due to surfaces which are thinner than the bronze Kulintangan. Nowadays, the maker of the Kulintangan uses the electronic keyboard to determine the pitch of the Kulintangan. The zinc Kulintangan is usually painted silver whereas the bronze Kulintangan is not painted (informant).

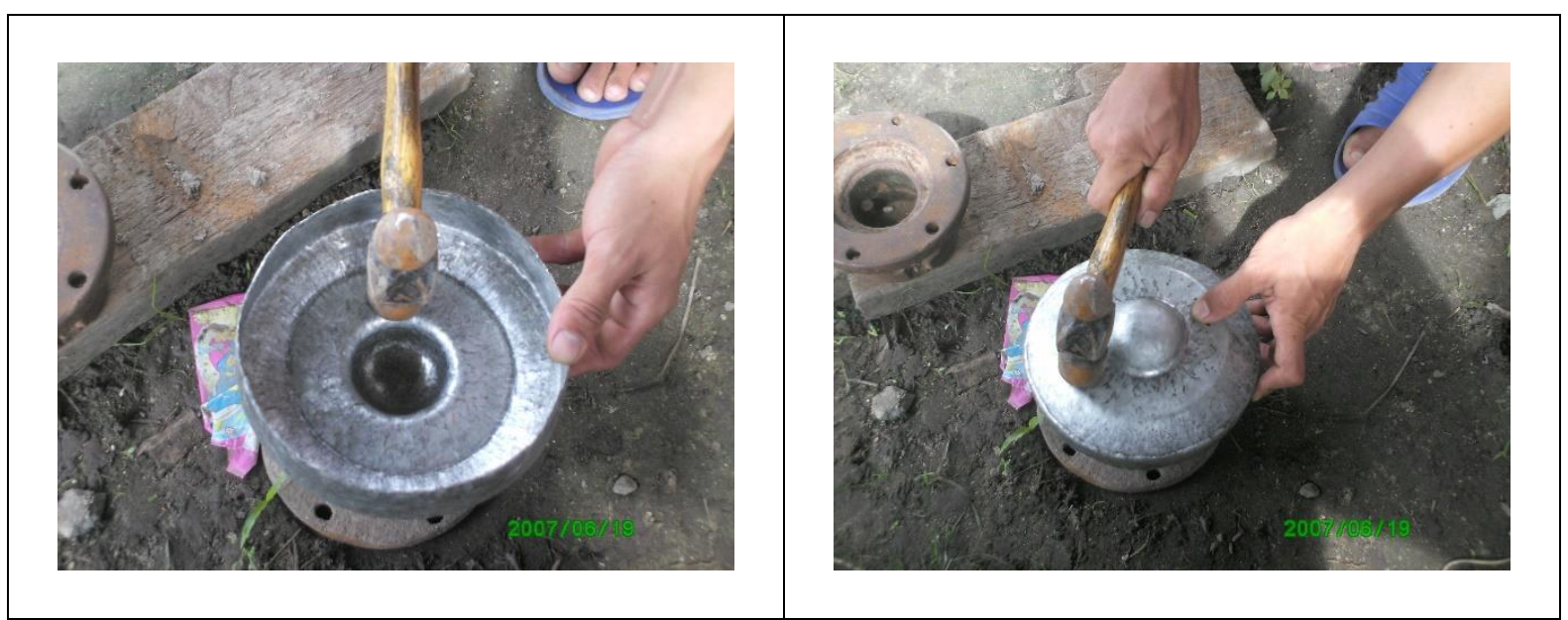

Figure 12: The $6^{\text {th }}$ Production Process Notation System

Because the Kulintangan was used to cater to indigenous communities, Kulintangan repertoire was unfettered by any notation system. Music arrangement was passed down vocally from generation to generation, negating the need for notation to preserve traditional music. Recent efforts have been made to record and transcribe the music using western notation system, designated by a numbering system. Music arrangement of the Kulintangan may vary from one ethnic group to another; however, the art of adlibbing is frequently used in most music arrangement.

When performed as a solo performance, both hands will have separate role. The right hand of the performer will play the melodic phrase of the music arrangement, whereas the left hand role is to support the melodic phrases with a supporting rhythmic pattern. Both hands are equally vital in a solo performance. However, if the Kulintangan is performing in an ensemble setting it will generally hold the melodic phrases of the repertoire perform.

\section{References}

Mudi, A. 1995. Kajian Muzik Sabah. Kota Kinabalu: Perpustakaan Negeri Sabah.

Beegle, A. C. 2012. World music ensemble: Kulintang. General Music Today 25(3): 58-60.

Benggon-Vharuruks, I, Padasian, J. 1992. Cultures, Customs, and Traditions of Sabah Malaysia. An Introduction.

Dontsa, L. 2008. From the museum to the music classroom: Teaching the Umrhubhe as an ensemble instrument. International Journal of Music Education 26(2): 177-190.

Han, K. H. 2002. Introducing Southest Asian group music to general music classrooms. General Music Today 16: 9-12.

Ibrahim, J. (1982). Alat Muzik Tradisional Sabah: Mitos Di Sebalik Penciptaannya. Dewan Budaya. 
Pugh-Kitingan, J. 2010b. From Brunei? Preliminary enquiries about Iranun Gong-making and metalwork at tempasuk, Sabah, Malaysia. In Piakandatu ami Dr. Howard P. McKaughan, eds. L. Billings and N. Goudswaarde, 225-229 (with photographs on CD). Manila: Linguistic Society of the Philippines and SIL Philippines.

Pugh-Kitingan, J. 1987. A Brief Introduction to Sabah Culture and Music. Kota kinabalu: Sabah Museum and Archives Journal.

Pugh-Kitingan, J. 2004. Selected papers on music in Sabah. Kota Kinabalu: Kadazandusun Chair, Universiti Malaysia Sabah.

Regis, P. (1995). Pengenalan Kepada Alat-alat Muzik Tradisional Sabah. Kota Kinabalu: Jabatan Muzium dan Arkib Negeri Sabah.

Schmid, W. 1992. World Music in the instrumental program. Music Educators Journal 78: 4145.

Simeon, J. J. C 2015. The U9 Xylophone: An Innovation in Music Classroom Teaching. Wacana Seni Journal of Arts Discourse. Jil./Vol.14. Universiti Sains Malaysia.

Smith, K. H. 2011. The five-string Banjo in music classroom. General Music Today 25(1): 1926.

Tahir, R. M., Ghazali, G. M. 2006. Music Teacher Training Programs in Malaysia: Snapshots and Reflections of the Current Scenario. Perspectives on Music Education in Malaysia.

Tan. S. B. 1998. Penghantar Muzik Malaysia, Buku 1: The Asian Centre, Pulau Pinang, Malaysia.

\section{Informants}

Danny@Haniff. 2006. Kg. Kuai Kandazon Penampang, interviewed on Dec

Ghafar binNarudin. 2007. Kg Kuai Kandazon Penampang, interviewed on May

Lenny Lyne@Maurice 2007. Kg Kandazon Penampang, interviewed on May

Jamali bin Matinggal. 2007. Kg. Sumangkap Kudat, interviewed on May

Jasmi bin Semun. 2007. Kg. Sumangkap Kudat, interviewed on May 